\title{
Chondrogenic Differentiation of Bone Marrow Mesenchymal Stem Cells. First Successful Latin-American Report
}

\author{
Diferenciación Condrogénica de Células Madres Mesenquimáticas de Médula Osea. \\ Primer Reporte Exitoso Latinoamericano
}

*,**,**** Rodrigo Mardones; ${ }^{* *, * * *, * * * * *}$ Rafael Martínez; ${ }^{* * * * * *}$ María Jose Paredes \& ${ }^{* * * *}$ Eugenio Zalaquett

MARDONES, R; MARTÍNEZ, R.; PAREDES, M. J. \& ZALAQUETT, E. Chondrogenic differentiation of bone marrow mesenchymal stem cells. First successful Latin-American report. Int. J. Morphol., 28(3):749-754, 2010.

SUMMARY: Osteoarthritis is the more frequent cause of disability in adult people and it is associated to cartilage degeneration of affected joints. This cartilage has a limited ability to repair. Several treatments have been tested including the use of Mesenchymal Stem Cells. These cells are an attractive source for cartilage repair because of their availability to chodrogenic differentiation by progressing sequentially through the expression of cartilage specific extracelullar matrix molecules, as in the embryologic human development. The aim is to obtain, culture and differentiate rabbit Bone Marrow derived Mesenchymal Stem Cells in vitro to chondral lineage. By differential centrifugation the mononuclear cell level was obtained from rabbit bone marrow samples. This level was cultured until $70 \%$ confluence. Chondrogenic differentiation was performed in an aggregate culture system with TGF-b1. Sample quantity, culture efficiency, confluence time of cultures and differentiation quality were all evaluated. An average sample of $14.5 \mathrm{ml}$ per side was obtained, culture efficiency was $80 \%$, and average confluence time (70\%) was 18 days. Differentiation culture had an $80 \%$ efficiency and optimal differentiation quality. Rabbit Bone Marrow derived Mesenchymal Stem Cells culture is a reproducible technique and by the use of an adequate methodology chondrogenic cells can be obtained in vitro. This model permits the study of chondral differentiation process and could have direct clinical application. This is the first successful Latin-American report in Mesenchymal Stem Cells culture and chondrogenic differentiation.

KEY WORDS: Chondrogenic differentiation; Mesenchymal Stem Cells; Osteoarthritis.

\section{INTRODUCTION}

Osteoarthritis (OA) is the most common cause of longterm disability in most populations of people over 65 years old and is one of the leading causes of invalidity in adults (Buckwalter et al., 2004). In this disease the articular cartilage and subchondral bone of the affected joints are damaged. Unfortunately, damaged articular cartilage has a limited ability to heal (Redman et al., 2005). In order to achieve a biological cartilage repair clinicians and basic researchers have been exploring different alternatives being tissue engineering with different cell types is one of the most promising currents.

Mesenchymal stem cells (MSCs), one type of adult stem cell, were initially identified in postnatal bone marrow (BM) and later in peripheral blood, periosteum, muscle, adipose tissue, and connective tissue (Pittenger et al., 1999; Vaananen, 2005; Zuk et al., 2001; Zvaifler, 2000). These cells are easy to isolate, culture, and manipulate in vitro and have great plasticity; for these reasons they have become an important tool in cell replacement therapy and are presently considered as candidates for different clinical applications (Vaananen; Bongso \& Richards, 2004). MSCs still lack a defined panel of characterized surface markers. Thus, for the final definition of MSC are necessary retrospective experiments where the theorical MSCs are able to differentiate towards adult tissue lineages (Dominici et al., 2006).

The most popular source of MSCs is the Bone Marrow (BM) (Vaananen; Bianco et al., 2001) and the

* Department of Orthopedics, Clinica Las Condes, Santiago, Chile.

** Department of Orthopedics, Hospital Militar, Santiago, Chile.

**** Tissue Engineering Laboratory, Clinica Las Condes - Hospital Militar, Santiago, Chile.

***** Facultad de Ciencias de la Salud, Universidad Diego Portales, Santiago, Chile.

****** Department of Cellular and Molecular Biology, Pontificia Universidad Católica de Chile, Santiago, Chile. 
chondrogenic capacity of BMMSCs has been shown by Shapiro et al. (1993) in spontaneous healing models of full thickness chondral lesion in short term follow up. Unfortunately, the phenomenon of spontaneous healing does not result in long-term functional cartilage repair. Johnstone et al has developed a culture system that facilitates the chondrogenic differentiation of postnatal mammalian marrow mesenchymal progenitor cells (Johnstone et al., 1998). This aggregate culture system allows cell-cell interactions analogous to those that occur in precartilage condensation during embryonic development. However, this cell configuration alone is not sufficient for the induction of chondrogenesis. A defined medium containing TGF- $\beta$ is required for the chondrogenic differentiation of the marrow-derived progenitor cells (Johnstone et al., 1998). The aim of this research was to achieve the isolation, culture and chondrogenic differentiation of rabbit BMMSCs.

\section{MATERIAL AND METHOD}

Bone marrow punctures. According to the ethic recommendation of The American Physiological Society, 12 four month old New Zealand male rabbits were anesthetized by intramuscular injection of a mixture of ketamine hydrochloride $20 \mathrm{mg} / \mathrm{kg}$ and xylazine $5 \mathrm{mg} / \mathrm{kg}$. An iliac puncture was performed percutaneously with sterile technique over each iliac crest, with a 14 Fr Thuoy trocar. $\mathrm{BM}$ aspirate (BMA) was collected in a syringe with $1 \mathrm{ml}$ of heparin (5,000 units per $\mathrm{ml})$, and sterile phosphatebuffered saline (PBS) 1x was added in a 1:1 relation (Mardones et al., 2005; Urrutia et al., 2010) (Fig. 1a).

Bone Marrow Aspirate Preparation. In a conical tube 4 $\mathrm{ml}$ of Histopaque-1077 (SigmaAldrich, St. Louis, MO, USA) were added, followed by $6 \mathrm{~mL}$ of the BMA/PBS $1: 1$. The aspirate was then centrifuged at $400 \mathrm{~g}$ for $30 \mathrm{~min}$ and a density gradient was performed and the mononuclear level was visualized (Mardones et al.; Urrutia et al.).

MSCs culture . The mononuclear level (containing MSCs) was aspirated and washed with PBS 1X, the cellular number was determined with hemocytometer and the cells were seeded in $1 \mathrm{X} 106$ cells $/ \mathrm{ml}$ concentration in a Petri dish with expansive medium: Dulbecco's Modified Eagle Media (DMEM) (Invitrogen, Carlsbad, CA, USA), 10\% fetal bovine serum (Invitrogen, Carlsbad, CA, USA), Pen/Strep/ Amphotericin B (100 U/mL and $100 \mathrm{mg} / \mathrm{mL} / 250 \mathrm{mg} / \mathrm{mL})$ (Invitrogen, Carlsbad, CA, USA). Cells were maintained in a humidified atmosphere of $5 \% \mathrm{CO}_{2}$ at $37^{\circ} \mathrm{C}$. The medium was changed on the third day and every other day thereafter and the unattached cells in suspension were discarded, while the adherent cells were further cultured, achieved at least $70 \%$ of confluence. At that moment the cells were trypsinizated with $0.25 \%$ trypsin/ 0.001 M EDTA (Invitrogen, Carlsbad, CA, USA) and chondrogenic differentiation was performed (Mardones et al.; Urrutia et al.).

Chondrogenic Differentiation. Aliquots 2 x 105 MSCs (calculated by hemocytometer) were centrifugated at $550 \mathrm{~g}$ in $15 \mathrm{ml}$ polypropylene tubes (Falcon, Bedford, MA) for 5 minutes. The expansive medium was replaced by a chondrogenic medium: DMEM (Invitrogen, Carlsbad, CA, USA) with TGF-B1 $10 \mathrm{ng} / \mathrm{ml}$ (Becton and Dickinson, Franklin Lakes, NY, USA), $50 \mathrm{mg} / \mathrm{ml}$ ITS + Premix (Becton and Dickinson, Franklin Lakes, NY, USA) and $37.5 \mathrm{mg} / \mathrm{ml}$ ascorbate 2-phosphate (Sigma-Aldrich Corp., St. Louis, MO, USA). The pelleted cells were incubated in a humidified atmosphere of $5 \% \mathrm{CO}_{2}$ at $37^{\circ} \mathrm{C}$. Medium was changed every 3 days and the pellets were harvested after 21 days of culture (Johnstone et al.).

Evaluation of Chondrogenic Differentiation. The chondrogenic differentiation was evaluated by histomorphometric analysis. This analysis was performed in The Cartilage and Connective Tissue Research Laboratory (Mayo Clinic College of Medicine, MN, USA). Briefly, after 21 days in culture the explants were fixed in $10 \%$ neutral formalin buffer, embedded in paraffin and the samples were shipped to the Mayo Clinic were $3-\mu \mathrm{m}$ thick sections were cut from a centrally located portion and stained for histological and immunohistochemical analysis. Sections stained with safranin O/fast green and explants were analyzed by a computer image analysis system (VIDAS 2.1 by Kontron Electronik, customized by Carl Zeiss Canada, Don Mills, Ontario, Canada) as described before (O'Driscoll et al., 1999). The pellets were classified by a simple histological-histochemical cartilage scoring system previously validated (Im et al., 2001).

\section{RESULTS}

Bone Marrow Punctures and Density Gradient. $12 \mathrm{New}$ Zealand rabbits were punctured as described previously (Fig. 1a). The average volume of BMA was $14.5(20-8.5) \mathrm{ml}$ per side. After density gradient, we observed four different density levels, red blood cells at the bottom, Histopaqueâ 1077 (Sigma, St. Louis, MO), mononuclear cell level and plasma, as described previously (Mardones et al.; Urrutia et $a l$.). The average of mononuclear level was $3.2 \mathrm{ml}$ (2.5-3.7 ml) (Fig. 1b). 

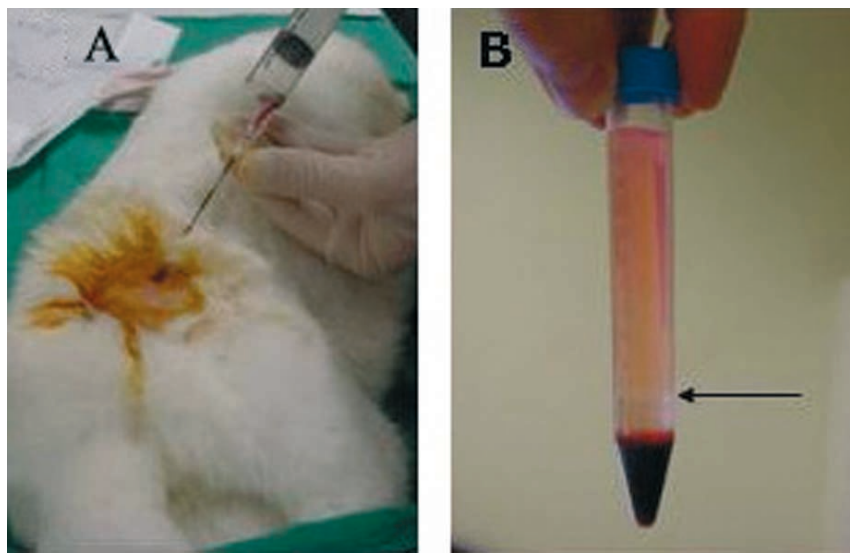

Fig. 1. Bone Marrow Punctures and Density Gradient. A) Percutaneous Iliac Puncture: BMA can be observed in the syringe. B) Mononuclear level showed by the arrow.

Primary cultures. In the mononuclear level 690,000 cels/ $\mathrm{ml}$ were obtained. The cultures were evaluated by phase contrast microscopy; this methodology has long been used to demonstrate changes in the morphology of the MSCs with time in culture (Mets \& Verdonk, 1981). 15 primary cultures were performed and the efficiency of the primary cultures was $80 \%$ ( 12 cultures). 3 cultures were eliminated because contamination was detected ( 2 cultures presented fungal contamination and 1 culture presented bacterial contamination). MSCs easily expanded in vitro: at day 3 the cells in all cultures were adherent, at day 6 in all cultures cells with spindle-shaped morphology (fibroblast-like morphology) was visible, characteristic of MSCs and at day 18 the remaining 12 cultures achieved $70 \%$ of confluence (Fig. 2).

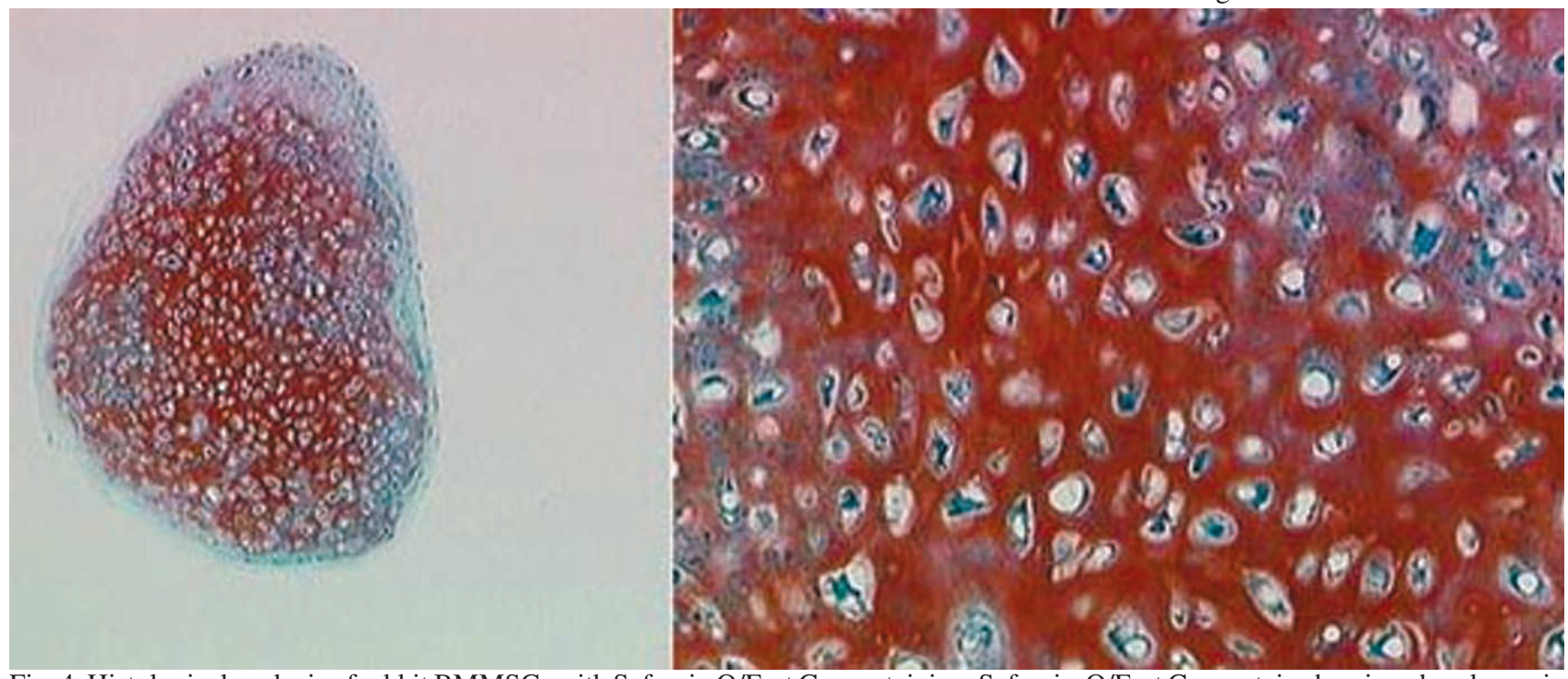

Fig. 4. Histological analysis of rabbit BMMSCs with Safranin O/Fast Green staining. Safranin-O/Fast Green stain showing chondrogenic differentiation of rabbit BMMSCs in a 21 day pellet culture with TGF-b1 $(10 \mathrm{ng} / \mathrm{ml})$.

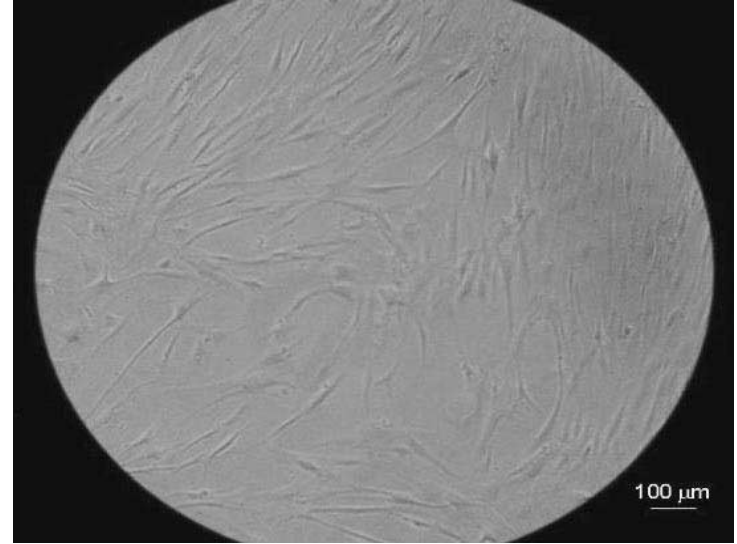

Fig. 2. Bone Marrow Mesenchymal Stem Cells Culture. Rabbit BMMSCs with $50 \%$ of confluence. The cells exhibited a fibroblast-like morphology, characteristic of MSCs. Bar: $100 \mathrm{~mm}$

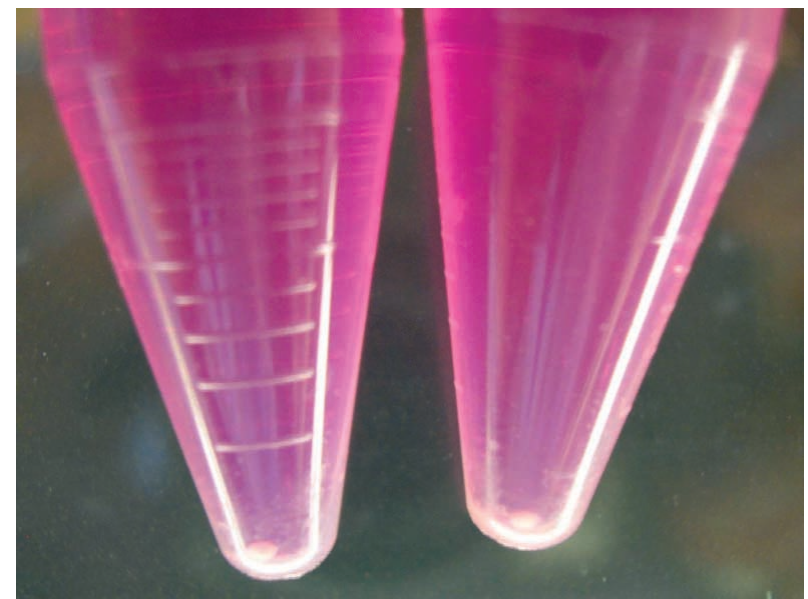

Fig. 3. Chondrogenic Differentiation: Aggregate pellet culture. Aliquots of rabbit BMMSCs forming a spherical pellet in differentiation medium containing TGF-b1. 
Chondrogenic Differentiation. Rabbit BMMSCs (Fig. 2) were cultured up to 21 days in aggregate culture system and were stimulated with TGF-b1 (10 ng/ml). 12 pellets were performed and at day 2 of chondrogenic cultures a spherical shaped pellet was visible in all pellets (Fig. 3). At day 21 the quality of differentiation was evaluated by histomorphometric analysis (Fig. 4) and then classified by histological-histochemical cartilage scoring system. 10 pellet (83\%) showed score 3 (almost complete differentiation), 1 pellet (8.5\%) showed score 2 (moderate differentiation) and $1(8.5 \%)$ showed score 1 (slight differentiation) (Fig. 5).

\section{Chondrogenic Diferentiation (Score Im G et al)}

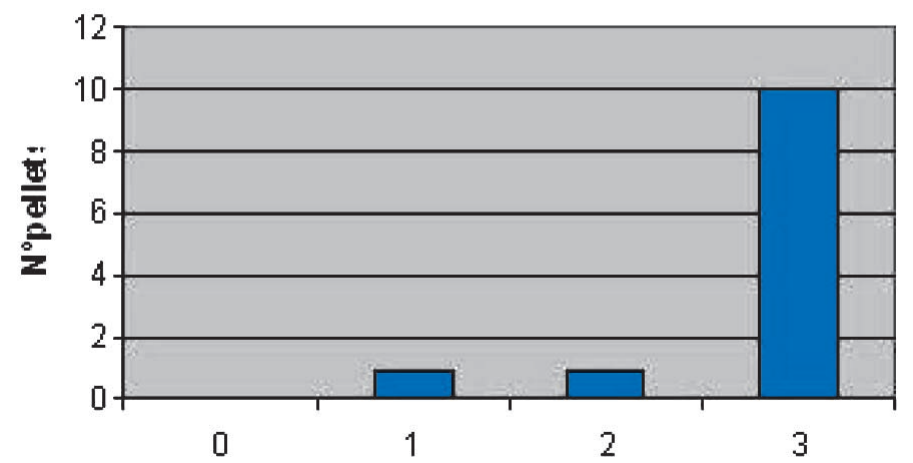

Histologica-histochemical catilage score

Fig. 5. Quality of chondrogenic differentiation of rabbit BMMSCs. Quality of chondrogenic differentiation of rabbit BMMSCs. 10 pellet $(83 \%)$ showed score 3,1 pellet $(8.5 \%)$ score 2 and 1 pellet score 1 .

\section{DISCUSSION}

Mesenchymal stem cells (MSC) are adult stem cells typically obtained from different sources (including bone marrow) and they have multilineage potential in vitro. Because they are able to undergo chondrogenic commitment they are of great interest in articular cartilage engineering (Redman et al.; Mardones et al.). In this report we demonstrated the ability to obtain, expand and differentiate to chondral lineage with optimal quality rabbit BMMSCs. As far as the authors know this represents the first report in our country.

Although the BMA is highly cellular, the hematopoietic lineages is the main fraction of the cells and only a small proportion of its cells are part of the mesenchymal lineage (Zvaifler et al.). The principal difficulty to culture MSCs is the fact a surface antigen that can be used to positively identify the cells does not exist (Bongso \& Richards, 2004; Dominici et al.). In this paper we have shown that these rabbit BMMSCs were capable of differentiating efficiently into chondrogenic cell types under specific culture conditions in vitro and, for this reason, we retrospectively demonstrate the potential of these cells to differentiate towards adult tissue lineages. To achieve the commitment of the rabbit BMMSCs into chondrocytes we stimulated these by continuous TGF- $\beta 1$ treatment in aggregate culture. In this system, the aggregates synthesizes an extracellular matrix characteristic of cartilage, containing proteoglycan and type II collagen faithfully reproducing the complex molecular events of chondrocyte differentiation and then long-term maintenance of the articular cartilage phenotype as in the embryologic human development and require the coordinate expression of multiple genes using complex regulatory systems. Under these conditions the chondral differentiation was optimal as demonstrated by histomorphometric analysis that have been shown to be reproducible and to accurately represent the percentage of cartilage in a sample (O'Driscoll et al., 1999). The analysis of cartilage is based on the uptake of Safranin O, with the thresholds and combinations of red, green and blue colors distinguished automatically. With the cartilaginous areas staining red with fast green, the computer calculates the cartilage yield (percent area of cartilage) in each explant by measuring the red-stained region of the histological section and by expressing it as a percentage of the whole section area (O'Driscoll et al., 1985). Then a simple histological-histochemical cartilage scoring system validated previously (Im et $a l$.) was used to analyze all the samples.

In conclusion, our results have demonstrated that it is possible to achieve the isolation, culture and chondrogenic differentiation of the rabbit BMMSCs in the Chilean reality. We predict that the results of this study will have a significant impact in both the basic and clinical Chilean research because MSCs represents a promising tool for understanding tissue development and regeneration of damaged tissues.

MARDONES, R; MARTÍNEZ, R.; PAREDES, M. J. \& ZALAQUETT, E. Diferenciación condrogénica de células madres mesenquimáticas de médula ósea. Primer reporte exitoso Latinoamericano. Int. J. Morphol., 28(3):749$754,2010$.

RESUMEN: La osteoartritis es la causa más frecuente de discapacidad en personas adultas y se asocia a la degeneración de los cartílagos de las articulaciones afecta- 
das. Este cartílago tiene una capacidad limitada a la reparación. Muchos tratamientos han sido probados, incluyendo el uso de células madre mesenquimáticas. Estas células son una fuente atractiva para la reparación del cartílago debido a su disponibilidad a la diferenciación condrogénica progresando de forma secuencial a través de la expresión de moléculas de la matriz del cartílago específicos extracelular, como en el desarrollo humano embrionario. El objetivo es obtener, el cultivo y la diferenciación células madre mesenquimáticas de conejo procedentes de médula ósea al linaje condral in vitro. Por centrifugación diferencial a nivel de células mononucleares se obtuvieron muestras de médula ósea de conejo. Este nivel se cultivó hasta su confluencia al 70\%. La diferenciación condrógenica se realizó en un sistema de cultivo de agregado con el TGF-b1. La cantidad de muestra, la eficiencia cultura, el tiempo confluencia de cultivos y la calidad de la diferenciación fueron evaluadas. Una muestra media de $14,5 \mathrm{ml}$ por lado fue obtenida, la eficiencia de cultivo fue del $80 \%$, y el tiempo promedio de confluencia (70\%) fue de 18 días. En la diferenciación del cultivo se obtuvo una eficiencia del $80 \%$ y con una calidad óptima de diferenciación. El cultivo de células madre mesenquimáticas derivadas de médula ósea de Conejo es una técnica reproducible y con el uso de una metodología adecuada células condrogénica se pueden obtener in vitro. Este modelo permite el estudio del proceso de diferenciación condral y podría tener una aplicación clínica directa. Este es el primer informe de éxito de América Latina en el cultivo de células madre mesenquimáticas y diferenciación condrogénica.

PALABRAS CLAVE: Diferenciación condrógenica; Células madre mesenquimáticas; Osteoartritis.

\section{REFERENCES}

Bongso, A. \& Richards, M. History and perspective of stem cell research. Best Pract. Res. Clin. Obstet. Gynaecol., 18:827-42, 2004.

Buckwalter, J. A.; Saltzman, C. \& Brown, T. The impact of osteoarthritis: implications for research. Clin. Orthop. Relat. Res., 427:S6-15, 2004.

Bianco, P.; Riminucci, M.; Gronthos, S. \& Robey, P. G. Bone marrow stromal stem cells: nature, biology, and potential applications. Stem Cells, 19:180-92, 2001.

Im, G. I.; Kim, D. Y.; Shin, J. H.; Hyun, C. W. \& Cho, W. H. Repair of cartilage defect in the rabbit with cultured mesenchymal stem cells from bone marrow. J. Bone Joint Surg. Br., 83:289-94, 2001.

Johnstone, B.; Hering, T. M.; Caplan, A. I.; Goldberg, V. M. \& Yoo, J. U. In vitro chondrogenesis of bone marrowderived mesenchymal progenitor cells. Exp. Cell Res., 238:265-72, 1998.
Dominici, M.; Le Blanc, K.; Mueller, I.; Slaper-Cortenbach, I.; Marini, F.; Krause, D.; Deans, R.; Keating, A.; Prockop, Dj. \& Horwitz, E. Minimal criteria for defining multipotent mesenchymal stromal cells. The International Society for Cellular Therapy position statement. Cytotherapy, 8(4):315-7, 2006.

Mardones, R. M.; Reinholz, G. G.; Fitzsimmons, J. S.; Zobitz, M. E.; An, K. N.; Lewallen, D. G.; Yaszemski, M. J. \& O'Driscoll, S. W. Development of a biologic prosthetic composite for cartilage repair. Tissue Eng., 11:1368-78, 2005.

Mets, T. \& Verdonk, G. In vitro aging of human bone marrow derived stromal cells. Mech. Ageing Dev., 16:81-89, 1981.

O'Driscoll, S. W.; Salter, R. B. \& Keeley, F. W. A method for quantitative analysis of ratios of types I and II collagen in small samples of articular cartilage. Anal. Biochem., 145:277-85, 1985.

O'Driscoll, S. W.; Marx, R. G.; Fitzsimmons, J. S. \& Beaton, D. E. Method for automated cartilage histomorphometry. Tissue Eng., 5:13-23, 1999.

Pittenger, M. F.; Mackay, A. M.; Beck, S. C.; Jaiswal, R. K.; Douglas, R.; Mosca, J. D.; Moorman, M. A.; Simonetti, D. W.; Craig, S. \& Marshak, D. R. Multilineage potential of adult human mesenchymal stem cells. Science, 284:143-7, 1999.

Redman, S. N.; Oldfield, S. F. \& Archer, C. W. Current strategies for articular cartilage repair. Eur. Cell Mater., 9:23-32, 2005.

Shapiro, F.; Koide, S. \& Glimcher, M. J. Cell origin and differentiation in the repair of full-thickness defects of articular cartilage. J. Bone Joint Surg. Am., 75:532-53, 1993.

Urrutia, J.; Mery, P.; Martínez, R.; Pizarro, F.; Apablaza, D. \& Mardones, R. Cultured autologous bone marrow stem cells inhibit bony fusion in a rabbit model of posterolateral lumbar fusion with autologous bone graft. J. Clin. Neurosci., 17(4):481-5, 2010.

Vaananen, H. K. Mesenchymal stem cells. Ann. Med., 37:469-79, 2005.

Zuk, P. A.; Zhu, M.; Mizuno, H.; Huang, J.; Futrell, J. W.; Katz, A. J.; Benhaim, P.; Lorenz, H. P. \& Hedrick, M. H. Multilineage cells from human adipose tissue: implications for cell-based therapies. Tissue Eng., 7:21128, 2001. 
MARDONES, R; MARTíneZ, R.; PAREDES, M. J. \& ZALAQUETT, E. Chondrogenic differentiation of bone marrow mesenchymal stem cells. First successful Latin-American report. Int. J. Morphol., 28(3):749-754, 2010.

Zvaifler, N. J.; Marinova-Mutafchieva, L.; Adams, G.; Edwards, C. J.; Moss, J.; Burger, J. A. \& Maini, R. N. Mesenchymal precursor cells in the blood of normal individuals. Arthritis Res., 2:477-88, 2000.
Correspondence to:

Rafael Martínez.

Laboratorio Fisiología Integrativa. Independencia 1027, Santiago CHILE

Phone: 56-02-9786038, 56-09-98178413.

Email: doctormartinez@gmail.com

Received: 03-06-2010

Accepted: 08-07-2010 